\title{
Histone H2A Type 1-D
}

National Cancer Institute

\section{Source}

National Cancer Institute. Histone H2A Type 1-D. NCI Thesaurus. Code C162897.

Histone H2A type 1-D (130 aa, 14 kDa) is encoded by the human H2AC7 gene. This protein is involved in the modulation of nucleosome structure. 